\title{
Distal Bile Duct Cancer pTX TNM Finding v8
}

National Cancer Institute

\section{Source}

National Cancer Institute. Distal Bile Duct CancerpTX TNM Finding v8. NCI Thesaurus.

Code C134798.

Distal bile duct cancer in which the primary tumor cannot be assessed. (from AJCC 8th Ed.) 